\title{
Temporal and spatial analysis of psittacosis in association with poultry farming in the Netherlands, 2000-2015
}

\author{
Lenny Hogerwerf ${ }^{1 *}$ (D), Manon M. C. Holstege ${ }^{1,2}$, Elisa Benincà ${ }^{1,3}$, Frederika Dijkstra $^{1}$ and Wim van der Hoek
}

\begin{abstract}
Background: Human psittacosis is a highly under diagnosed zoonotic disease, commonly linked to psittacine birds. Psittacosis in birds, also known as avian chlamydiosis, is endemic in poultry, but the risk for people living close to poultry farms is unknown. Therefore, our study aimed to explore the temporal and spatial patterns of human psittacosis infections and identify possible associations with poultry farming in the Netherlands.

Methods: We analysed data on 700 human cases of psittacosis notified between 01-01-2000 and 01-09-2015. First, we studied the temporal behaviour of psittacosis notifications by applying wavelet analysis. Then, to identify possible spatial patterns, we applied spatial cluster analysis. Finally, we investigated the possible spatial association between psittacosis notifications and data on the Dutch poultry sector at municipality level using a multivariable model.
\end{abstract}

Results: We found a large spatial cluster that covered a highly poultry-dense area but additional clusters were found in areas that had a low poultry density. There were marked geographical differences in the awareness of psittacosis and the amount and the type of laboratory diagnostics used for psittacosis, making it difficult to draw conclusions about the correlation between the large cluster and poultry density. The multivariable model showed that the presence of chicken processing plants and slaughter duck farms in a municipality was associated with a higher rate of human psittacosis notifications. The significance of the associations was influenced by the inclusion or exclusion of farm density in the model.

Conclusions: Our temporal and spatial analyses showed weak associations between poultry-related variables and psittacosis notifications. Because of the low number of psittacosis notifications available for analysis, the power of our analysis was relative low. Because of the exploratory nature of this research, the associations found cannot be interpreted as evidence for airborne transmission of psittacosis from poultry to the general population. Further research is needed to determine the prevalence of C. psittaci in Dutch poultry. Also, efforts to promote PCR-based testing for C. psittaci and genotyping for source tracing are important to reduce the diagnostic deficit, and to provide better estimates of the human psittacosis burden, and the possible role of poultry.

Keywords: Psittacosis, Avian chlamydiosis, Zoonosis, Poultry, Spatial analysis

\footnotetext{
* Correspondence: lenny.hogerwerf@rivm.nl

${ }^{1}$ Centre for Infectious Disease Control, National Institute for Public Health and the Environment, Bilthoven, The Netherlands

Full list of author information is available at the end of the article
} International License (http://creativecommons.org/licenses/by/4.0/), which permits unrestricted use, distribution, and reproduction in any medium, provided you give appropriate credit to the original author(s) and the source, provide a link to the Creative Commons license, and indicate if changes were made. The Creative Commons Public Domain Dedication waiver (http://creativecommons.org/publicdomain/zero/1.0/) applies to the data made available in this article, unless otherwise stated. 


\section{Background}

Zoonoses, infections transmitted from animals to humans, are an emerging world-wide problem [1]. A still relatively neglected zoonosis is human psittacosis. Psittacosis, also named parrot disease and avian chlamydiosis in birds, is caused by the gram negative, obligatory intracellular bacterium Chlamydia psittaci (C. psittaci) [2]. It is a common infection in parrots and other birds that is mostly asymptomatic but can be fatal for these animals [3-5]. Birds shed the bacterium through various routes, such as faeces, urine, and nasal secretions [6]. Humans might subsequently inhale very fine droplets or dust particles contaminated with $C$. psittaci [6]. Infection in people can be asymptomatic but may also result in systemic illness, including pneumonia [4, 5]. Even though the pneumonia can be severe, with adequate treatment, fatalities are rare [4].

Human psittacosis occurs worldwide [5]. The disease is notifiable in several countries, including the Netherlands, but significant underreporting is likely [6]. Tests for $C$. psittaci are often not included in routine microbiological diagnostics or consist of serological tests that cannot provide conclusive evidence if only one serum sample is available. Notified cases are therefore likely to represent only a small portion of the actual number of infections. In a recent study in the Netherlands $4.8 \%$ (7/147) of patients with community-acquired pneumonia were diagnosed with human psittacosis [7]. Altogether there is an unclear estimate of the public health burden and primary sources of human psittacosis.

Human psittacosis outbreaks are often associated with pet (parrot-like) birds and bird gatherings [4, 5]. Still, psittacosis is found in 465 bird-species nowadays [3]. Wild birds, for example, are mentioned as a possible other source of human psittacosis $[8,9]$. Endemicity of C. psittaci is reported in poultry, including in commercially kept ducks [10-13], chickens [14, 15], and turkeys $[14,16]$. In addition, a recently described C. psittaci related species named $C$. gallinacea is found to be predominant in chickens with a so far unknown zoonotic potential [17-19]. Research in 10 Belgian turkey farms revealed $94 \%$ of the turkeys to be infected with C. psittaci [16]. In Belgian chicken farms, 18 out of 19 studied studied farms were infected with C. psittaci [15]. Recent research also points out a role of poultry (i.e. ducks, chickens and turkeys) in human psittacosis infections. Employment in poultry processing plants and/or poultry farms is increasingly demonstrated to be related to outbreaks of human psittacosis [5, 12, 14-16, 20]. People dealing with poultry regularly, for example farmers, poultry processing employees and veterinarians have a higher risk for infection with $C$. psittaci [5]. Previous studies in the Netherlands found a higher incidence of pneumonia around poultry farms [21, 22]. In Australia, rural environments were indicated as a risk factor for psittacosis [23]. These are possible indications that poultry farms might also lead to psittacosis in humans by indirect contact (airborne transmission) [24]. This would have substantial implications for current guidelines, source tracing and screening practices. In the present study, we aim to assess whether human psittacosis notifications in the general population are associated with presence of poultry farming and poultry processing plants in time and space.

\section{Methods}

\section{Study population and data description}

Data on 737 human cases of psittacosis notified in the Netherlands between 01-01-2000 and 01-09-2015, were used. These cases are notified by the regional public health services (GGD) in the online notification database Osiris and fulfil the national notification criteria for psittacosis: a positive polymerase chain reaction (PCR) or a combination of matching clinical characteristics and a fourfold titer rise using serology [6, 25]. Via Osiris, information regarding demographical and epidemiological data (including four digit postal code) was obtained. These anonymised data were available as part of routine surveillance and epidemiological studies at the National Institute for Public Health and the Environment, the Netherlands. Information was present on a possible/suspected occupational link and in some cases a likely origin of infection was mentioned. Cases related to known outbreaks were excluded to avoid distortion of the association under study $(N=36)$, as for these cases the origin of infection was already determined and not related to poultry. Other cases where a possible source of infection was mentioned, were taken into account since no conclusive evidence on the origin of infection was present. Therefore, in total, 700 human cases of psittacosis were included in the study.

\section{Data on poultry sector}

Data on various aspects of the Dutch poultry sector was acquired from the agricultural census of the Netherlands Enterprise Agency (rvo.nl), Ministry of Economic Affairs, which included information about all individual farms with poultry. Aggregated agricultural census data are available from Statistics Netherlands (CBS) [26]. One reference year, 2012, was chosen because of practical issues resulting from municipal reclassifications. In addition, very detailed information about individual farms was only available for the year 2012, including data on exact locations and the number of poultry, divided into different subspecies. Some farms had multiple locations; therefore, in some cases the number of poultry was divided over the locations. When possible, the poultry was re-assigned to one of the locations based on 
data per location from the internet and a provincial database of mandatory environmental licenses for keeping livestock (province of Utrecht) [27]. Only poultry farms with $\geq 500$ birds in total (all poultry present on the farm combined) were included in the analyses to prevent possible distortion by 'hobby animals'. Hobby animals were excluded because only information on hobby animals on farms was present, not on hobby animals in people's backyards because these are not included in the agricultural census. Poultry variables that were used in the study, aggregated at a municipality level, were: poultry density, poultry farm density, average poultry farm size, chicken processing plant presence, chicken presence, turkey presence, slaughter duck presence, layer presence, broiler presence and outdoor range layer presence. The variables are nested in structure and therefore we organized the variables into four levels with a growing specificity (illustrated in Fig. 1). In Table 1, the variables, both on the human and veterinary side, are listed and described briefly.

\section{Wavelet analysis}

In order to identify potential temporal patterns in the data of psittacosis notifications we performed wavelet analysis, a technique suited for non-stationary time series as is the case for many epidemiological data [28]. Wavelet analysis uses a local periodic function (the wavelet) to decompose fluctuations of time series observed during a small time interval into a series of different periodicities. The relative importance of periodicities (wavelet power) is then plotted in contour plots as a function of time. In this way, the periodicity and the timing of the fluctuations can both be determined. Further information on wavelet analysis is available elsewhere [29-33].

\section{Spatial scan statistics}

In order to detect spatial clusters of high rates of psittacosis we applied the SaTScan spatial statistics using the SaTScan software (SaTScan version 9.4) [34, 35]. The
Table 1 Description of outcome- and explanatory variables, at a municipality level

\begin{tabular}{|c|c|c|}
\hline Variables & Description & $\begin{array}{l}\text { Unit } \\
\text { (per municipality) }\end{array}$ \\
\hline \multicolumn{3}{|l|}{ Human } \\
\hline $\begin{array}{l}\text { Number of cases notified } \\
\text { per total person years }\end{array}$ & $\begin{array}{l}\text { Number of human } \\
\text { psittacosis infections } \\
\text { notified from 01-01-2000 } \\
\text { until 01-09-2015 } \\
\text { weighted against the } \\
\text { total person years based } \\
\text { on the reference year } \\
2012 \text { (population in } 2012 \\
\text { times } 14 \text { years). }\end{array}$ & $\begin{array}{l}\text { Number of } \\
\text { cases / total } \\
\text { person years }\end{array}$ \\
\hline \multicolumn{3}{|l|}{ Animal } \\
\hline Total poultry density & $\begin{array}{l}\text { The density of all poultry } \\
\text { combined. }\end{array}$ & Birds $/ \mathrm{km}^{2}$ \\
\hline $\begin{array}{l}\text { Total poultry farm } \\
\text { density }\end{array}$ & $\begin{array}{l}\text { The number of poultry } \\
\text { farms per } \mathrm{km}^{2} \text { times } \\
\text { factor } 100 .\end{array}$ & $\begin{array}{l}\text { Number of } \\
\text { farms }{ }^{*} 100 / \mathrm{km}^{2}\end{array}$ \\
\hline $\begin{array}{l}\text { Average poultry farm } \\
\text { size }\end{array}$ & $\begin{array}{l}\text { Average size of a poultry } \\
\text { farm. }\end{array}$ & Birds \\
\hline $\begin{array}{l}\text { Chicken processing plant } \\
\text { presence }\end{array}$ & $\begin{array}{l}\text { The presence of a } \\
\text { chicken processing plant. }\end{array}$ & Yes/no \\
\hline Chicken presence & $\begin{array}{l}\text { The presence of chickens } \\
\text { (both broilers and layers). }\end{array}$ & Yes/no \\
\hline Turkey presence & The presence of turkeys. & Yes/no \\
\hline Slaughter duck presence & $\begin{array}{l}\text { The presence of } \\
\text { slaughter ducks. }\end{array}$ & Yes/no \\
\hline Total broiler presence & $\begin{array}{l}\text { The presence of broilers } \\
\text { (including parents of } \\
\text { broilers) }\end{array}$ & Yes/no \\
\hline Total layer presence & $\begin{array}{l}\text { The presence of layers } \\
\text { (including parents of } \\
\text { layers). }\end{array}$ & Yes/no \\
\hline $\begin{array}{l}\text { Outdoor range layer } \\
\text { presence }\end{array}$ & $\begin{array}{l}\text { The presence of places } \\
\text { for layers with outdoor } \\
\text { range. }\end{array}$ & Yes/no \\
\hline
\end{tabular}

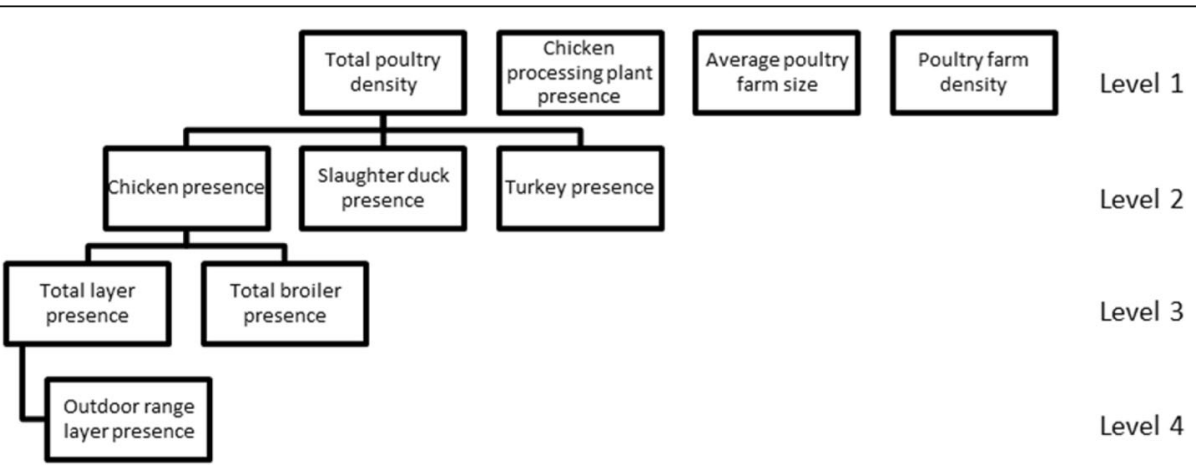

Fig. 1 Diagram describing the nested structure of poultry-related variables. The levels grow in specificity, where level 1 is the most general and level 4 is the most specific level 
total numbers of psittacosis notifications (2000-2015) and population numbers per four-digit postal code (reference year 2012) served as the analysis input. The location of the cases was set using the coordinates of the centroid of their four-digit postal codes. A Poisson scan statistic with a significance level of $P<=0.05$ was used and the maximum cluster size was set to $50 \mathrm{~km}$ radius, a distance sufficient to detect spatially concentrated clusters [36]. Resulting clusters were visually compared with poultry densities in the Netherlands to see if an association between them was plausible (farm infection status was not known).

\section{Spatial association between human psittacosis notifications and poultry}

We performed Poisson regression analyses in $\mathrm{R}$ software (v3.2.3.) [37], with the poultry-related variables as independent variables and the cumulative psittacosis notifications weighted against total person years as the dependent variable. The analyses were performed at the level of the municipality. There were 415 municipalities in the Netherlands in 2012. Neighbouring municipalities are presumably more alike, a phenomenon called spatial autocorrelation [38]. To account for spatial autocorrelation, a random effect term was added to the model. The complexity of the model requires a Bayesian approach, for instance using Markov chain Monte Carlo (MCMC). However, with MCMC, fitting the models would take a long time, therefore we used the much faster Integrated Nested Laplace Approximation (INLA). INLA is specifically suitable for the type of random effect terms we used. For analysis, the poultry-related density variables had to be divided into quantiles. The number of resulting quantiles was set to three or less (present/not present) in case of a lack of variability in density.

Univariable analyses were done for all poultry-related variables, to investigate their possible predictive role in the number of psittacosis cases (weighted against total person years). Subsequently, a multivariable model was created taking into account all variables regardless of the results during univariable analyses. The selection of variables to be included in the final multivariable model was based on the Deviance Information Criterion (DIC), an indicator of the quality of models similar to Akaikes Information Criterion (AIC), commonly used in Bayesian model selection. The nested data structure with four levels (as described under 'Study population and data description') required a non-standard approach of model selection. The starting model only included the most specific variable (level four) 'outdoor range layer presence'. Subsequently, the other variables were added one level at a time. A lower DIC of the new combined model allowed for inclusion of newly added variables. As a general rule, 'parent' variables (higher up in Fig. 1) were preferred over the combination of their more specific subset variables, when resulting in similar model quality. Every time a level was added, we looked for the combination of variables that gave the lowest DIC possible. Therefore, it was possible that only a selection of the variables from a specific level were added to the model. To check for robustness of the final model, model selection was also performed the other way round, starting with level one.

\section{Results}

From 01-01-2000 to 01-09-2015, 700 valid human cases of psittacosis were reported. The national median number of notifications per year (2000-2014) was 44 with a range from 12 to 77 . The distribution of the psittacosis notifications over four-digit postal codes and municipalities in The Netherlands is summarized in Table 2 and Table 3.

\section{Temporal and spatial patterns in the human psittacosis notifications}

The temporal dynamics of the psitaccosis notifications show strong variation among the months as well as among the years (Fig. 2a). In the first part of the time series (from 2000 to 2004), the number of notifications is quite low and substantially increases from 2004 onwards. Striking peaks in the number of notifications occur in the period spanning from the beginning of 2008 until the end of 2011. These peaks in notifications always occur during spring-summer months (March-July). This interesting seasonal pattern is confirmed by wavelet analysis, which identified a significant periodicity of about 12 months from the beginning of 2008 until the end of 2011 (Fig. 2b).

Spatial clusters analysis detected six significant clusters (Fig. 3a). F The analysis identified three large spatial clusters (numbers $1 / 2 / 3$ ) in the provinces of Gelderland and Overijssel. These include the area of the 'Gelderse Vallei', the main poultry production area of the Netherlands and other poultry dense municipalities (Fig $3 \mathrm{~b}$ ). In addition, clusters showed up in areas without poultry, (in Haarlem,

Table 2 Number of cases per four-digit postal code

\begin{tabular}{ll}
\hline Number of cases per four digit postal code & Frequency \\
\hline 0 & 3487 \\
1 & 447 \\
2 & 91 \\
3 & 21 \\
4 & 2 \\
\hline
\end{tabular}

Number of human cases of psittacosis notified per four digit postal code in the Netherlands between 01-01-2000 and 01-09-2015, with exception of cases related to known outbreaks. The median number of cases ( $n=700$ cases) per four-digit postal code area ( $n=4048$ areas) is zero, the mean number of cases is 0.17 , the standard deviation is 0.47 , and the variance is 0.23 
Table 3 Number of cases per municipality

\begin{tabular}{|c|c|c|}
\hline $\begin{array}{l}\text { Number of cases } \\
\text { per municipality }\end{array}$ & Frequency & Municipality names \\
\hline 0 & 152 & \\
\hline 1 & 114 & \\
\hline 2 & 60 & \\
\hline 3 & 42 & \\
\hline 4 & 11 & \\
\hline 5 & 12 & \\
\hline 6 & 8 & \\
\hline 7 & 2 & \\
\hline 8 & 2 & \\
\hline 9 & 4 & \\
\hline 10 & 2 & Utrecht, Barneveld \\
\hline 11 & 2 & Emmen, Haarlemmermeer \\
\hline 12 & 2 & Arnhem, Enschede \\
\hline 15 & 1 & Haarlem \\
\hline 41 & 1 & The Hague \\
\hline
\end{tabular}

Number of human cases of psittacosis notified per municipality in the Netherlands between 01-01-2000 and 01-09-2015, with exception of cases related to known outbreaks. For those municipalities with 10 or more cases, the name of the municipality is given. The median number of cases $(n=700$ cases) per municipality ( $n=415$ municipalities) is 1 , the mean number of cases is 1.69 , the standard deviation is 2.91 , and the variance is 8.46 number 4 and in and around The Hague, number 6)) or with moderate poultry density (in a rural area near Almelo, number 5).

\section{Spatial association between human psittacosis notifications and poultry}

In univariable analyses, all poultry-related variables with exception of presence of turkeys showed a slightly increased risk for psittacosis (Table 4). However, this increased risk was only statistically significant for chicken processing plant presence. The two multivariable model selection methods (starting at level one and four, selection based on DIC) gave similar results and included slaughter duck presence, chicken processing plant presence and poultry farm density in the final models. However, only chicken processing plant presence and slaughter duck farm presence were significantly associated with a higher incidence rate of psittacosis notifications in the multivariable model (Table 5). For farm density no clear trend was observed. Therefore, the final model is also presented without farm density (Table 5). The incidence rate ratios of the variables in the model altered slightly and were not significant anymore. Therefore, only when correcting for farm density a significant association between slaughter duck presence (Risk Ratio (RR): 1.44 [95\% Confidence Interval (CI) 1.01-2.05]), chicken processing plant
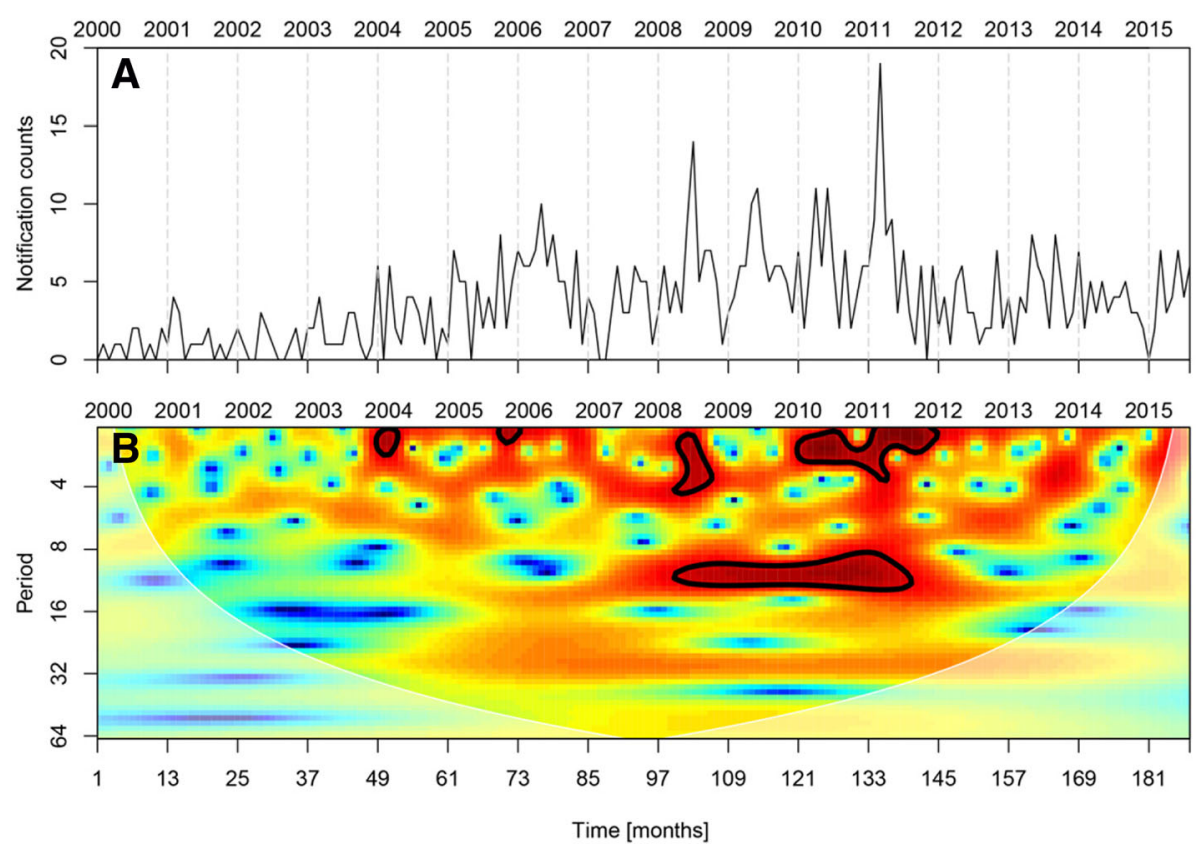

Fig. 2 Temporal dynamics of psittacosis notifications from 2000 to 2015 in the Netherlands. a Time series of psittacosis notifications plotted on monthly basis. $\mathbf{b}$ Wavelet power spectra of the psittacosis notifications. Color codes represent wavelet power and areas inside the black contour lines correspond to $95 \%$ confidence regions where the power is higher than the power of red noise with the same autocorrelation coefficient as the data. Transparent areas on the left and right hand sides of the plots represent the cone of influence, which is a region where edge effects are important 

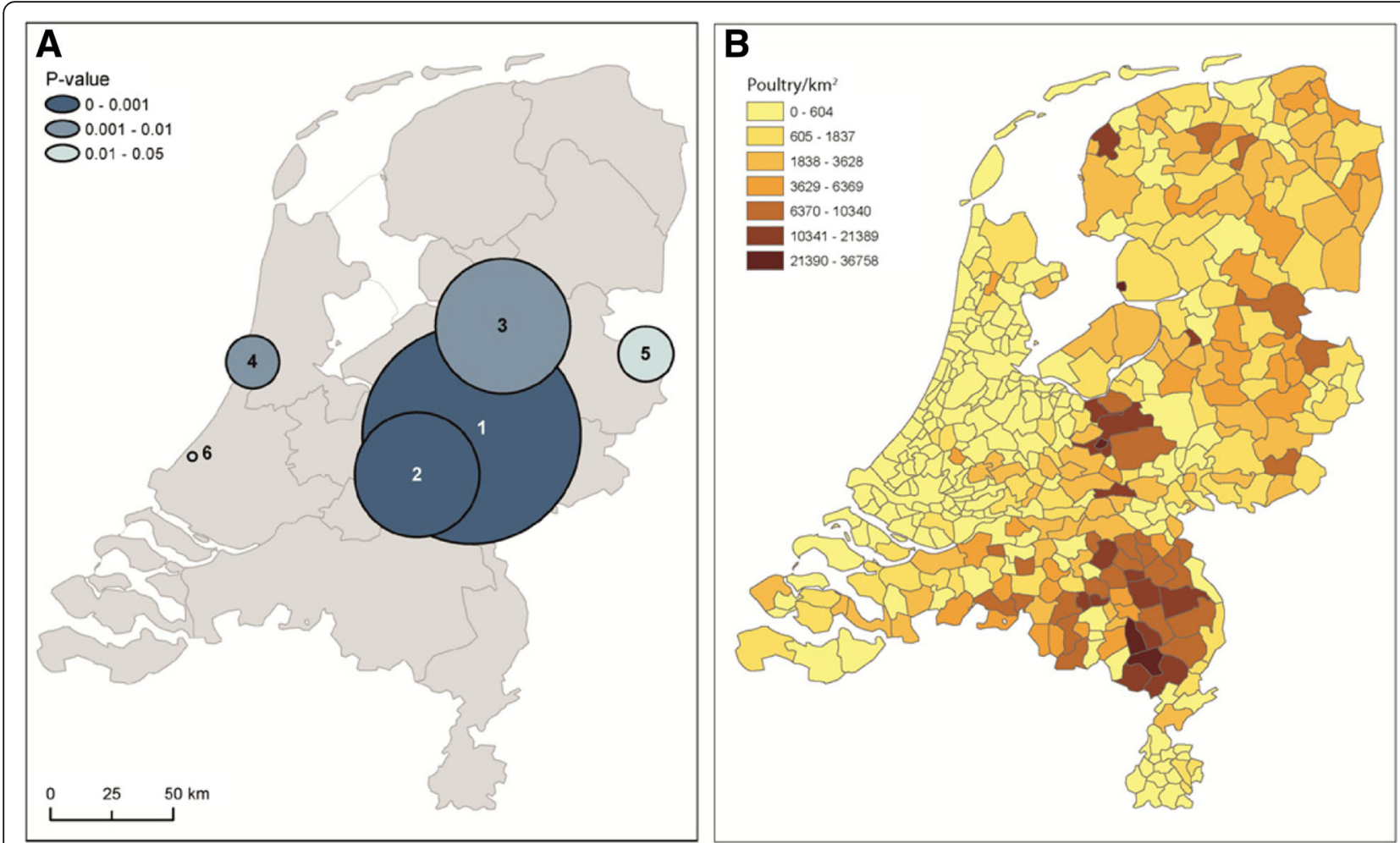

Fig. 3 Spatial dynamics of psittacosis notifications in relation to the density of poultry in the Netherlands. a Spatial clusters of the total number of psittacosis cases ( $N=701$; cases from known outbreaks were excluded) notified from 01-01-2000 until 01-09-2015. Black circles represent significant clusters $(P<=0.05)$ identified whilst imposing a maximum radius of the window of $50 \mathrm{~km}$. $\mathbf{b}$ Map of poultry density at municipality level. The poultry density data was obtained from Statistics Netherlands (CBS) [26]

presence (RR: 1.63 [95\% CI:1.03-2.53]) and the human psittacosis notification incidence is visible.

\section{Discussion}

\section{Temporal and spatial patterns in the human psittacosis} notifications

The temporal pattern of psittacosis showed variability in the number of notifications among the months as well as among the years. An interesting seasonal pattern has been identified with peaks in psittacosis notifications during the spring-summer months, but so far an explanation for this pattern is lacking. The number of psittacosis notifications is substantially increased from 2004 onwards. The rise in human psittacosis notifications may be explained by a higher incidence of infection, or more awareness about psittacosis and reduction of underdiagnosis. In the poultry sector, there was a trend towards fewer but larger farms (intensification) and a trend towards new housing systems for animal welfare, with a rise in the available space per bird, including a rise in outdoor range places. Coincidentally, from 2004 onwards, supermarkets in The Netherlands banned eggs from battery cages [39]. Recent studies show that the housing systems for layer hens that replaced the battery cages generate more dust, resulting in higher particulate matter emissions [40].

Spatial cluster analysis identified a large cluster, located in the middle-eastern part of the Netherlands. This cluster included the main Dutch poultry production area: the 'Gelderse Vallei' and other poultry dense areas. In the study by Spoorenberg et al. (2016), 7/147 (4.8\%) patients with community-acquired pneumonia were diagnosed with psittacosis [7]. Patients were from two hospitals, of which one was located in the poultry dense area of the Netherlands and within the large spatial cluster (cluster one) and the smaller cluster two [7].

While the large cluster could be associated with poultry farming, poultry is very unlikely to play a role in the other two spatial clusters in and around seaside cities. In these clusters, pet birds or wild birds are a possible source of infection $[4,5,8,9]$. There are likely to be regional differences in the awareness of psittacosis. For instance, the regional public health service and microbiological laboratory in the area of the Haarlem cluster (cluster number 4) were active in research into psittacosis, creating higher awareness [3]. Also, in some regions more diagnostic tests are performed than in other regions with important regional differences in use of PCR or serology as method of choice [7]. 
Table 4 Univariable RR with 95\% Cl for psittacosis notifications in the Netherlands, 01-01-2000 until 01-09-2015

\begin{tabular}{|c|c|}
\hline Variables & RR $(95 \% \mathrm{Cl})$ \\
\hline \multicolumn{2}{|l|}{ Total poultry density } \\
\hline 0 Birds $/ \mathrm{km}^{2}$ & 1.00 \\
\hline 0-1150 Birds/km² & $1.18(0.91-1.54)$ \\
\hline$>1150 \mathrm{Birds} / \mathrm{km}^{2}$ & $1.21(0.90-1.61)$ \\
\hline \multicolumn{2}{|l|}{ Poultry farm density } \\
\hline 0 Farms $/ \mathrm{km}^{2}$ & 1.00 \\
\hline 0-0.05 Farms $/ \mathrm{km}^{2}$ & $1.28(0.99-1.67)$ \\
\hline$>0.05$ Farms $/ \mathrm{km}^{2}$ & $1.06(0.79-1.42)$ \\
\hline \multicolumn{2}{|l|}{ Average poultry farm size } \\
\hline 0 Birds & 1.00 \\
\hline 0-21,000 Birds & $1.15(0.88-1.49)$ \\
\hline$>21,000$ Birds & $1.28(0.95-1.71)$ \\
\hline \multicolumn{2}{|l|}{ Chicken processing plant presence } \\
\hline No chicken processing plant present & 1.00 \\
\hline Chicken processing plant present & $1.58(1.01-2.43)$ \\
\hline \multicolumn{2}{|l|}{ Chicken presence } \\
\hline No chickens present & 1.00 \\
\hline Chickens present & $1.20(0.94-1.53)$ \\
\hline \multicolumn{2}{|l|}{ Turkey presence } \\
\hline No turkeys present & 1.00 \\
\hline Turkeys present & $0.92(0.59-1.41)$ \\
\hline \multicolumn{2}{|l|}{ Slaughter duck presence } \\
\hline No slaughter ducks present & 1.00 \\
\hline Slaughter ducks present & $1.40(0.99-1.97)$ \\
\hline \multicolumn{2}{|l|}{ Broiler presence } \\
\hline No broilers present & 1.00 \\
\hline Broilers present & $1.04(0.82-1.32)$ \\
\hline \multicolumn{2}{|l|}{ Layer presence } \\
\hline No layers present & 1.00 \\
\hline Layers present & $1.06(0.84-1.32)$ \\
\hline \multicolumn{2}{|l|}{ Outdoor range layer presence } \\
\hline No layers with outdoor range present & 1.00 \\
\hline Layers with outdoor range present & $1.06(0.84-1.33)$ \\
\hline
\end{tabular}

$N=415$ municipalities

\section{Spatial association between human psittacosis notifications and poultry}

Chicken processing plants and slaughter duck farms were significantly associated with human psittacosis notifications. However, the associations were not significant anymore when farm density was left out of the model.

The presence of C. psittaci on chicken processing plants and slaughter duck farms and occupational risks for the workers have been reported in studies in Belgium and France $[14,12,20]$. Dickx and Vanrompay (2011) detected
Table 5 Final multivariable models for psittacosis infection notifications in the Netherlands, 01-01-2000 until 01-09-2015

\begin{tabular}{lll}
\hline Variables & $\mathrm{RR}(95 \% \mathrm{Cl})$ & $\mathrm{RR}(95 \% \mathrm{Cl})$ \\
\hline $\begin{array}{l}\text { Chicken processing plant } \\
\text { presence }\end{array}$ & & \\
$\quad \begin{array}{l}\text { No chicken processing } \\
\text { plant present }\end{array}$ & 1.00 & 1.00 \\
$\begin{array}{l}\text { Chicken processing } \\
\text { plant present }\end{array}$ & $1.63(1.03-2.53)$ & 1.55 (0.99-2.38) \\
$\begin{array}{l}\text { Slaughter duck presence } \\
\quad \text { No slaughter ducks present }\end{array}$ & 1.00 & \\
$\quad \begin{array}{l}\text { Slaughter ducks present } \\
\text { Poultry farm density }\end{array}$ & $1.44(1.01-2.05)$ & 1.37 (0.97-1.94) \\
$\quad \begin{array}{l}\text { Farms } / \mathrm{km}^{2} \\
\text { 0-0.05 Farms } / \mathrm{km}^{2}\end{array}$ & 1.00 & Not included \\
$>0.05$ Farms $/ \mathrm{km}^{2}$ & $1.26(0.96-1.63)$ & \\
\hline $\mathbf{N}=415$ municipalities & $0.94(0.69-1.28)$ &
\end{tabular}

$N=415$ municipalities

C. psittaci in air samples of a poultry processing plant and found employees to be infected [14]. Hulin et al. (2015) showed a preference for ducks by C. psittaci combined with seroconversion in slaughterhouse employees [17]. Laroucau et al. (2009) showed chlamydial excretion in duck farms and human notifications of psittacosis on those farms with matching PCR patterns [12]. Laroucau et al. (2015) also showed human cases infected with the same C. psittaci genotype as the infected chickens they slaughtered [19]. Both chicken processing plants and slaughter duck farms have specific characteristics that may enhance indirect airborne transmission to the general population. In processing plants, stressed chickens enter in partly open crates [41]. Stress triggers the shedding of bacteria and via open crates, particles can easily become airborne [5]. A significant amount of dust is known to be generated at chicken processing plants and C. psittaci has been detected inside and at the open entrance of those processing plants [14]. In the case of slaughter duck farms, a lot of dust is created as well, due to the straw that the ducks live on and the relatively low bird density within farms in the Netherlands, allowing for movement and dust creation [42]. Ducks in the Netherlands are accommodated in closed buildings, but particulate matter emerges from ventilation systems and dust release might be enlarged while emptying and restocking [40]. In addition to the farm characteristics, it is important to note that ducks can be asympomatically infected while shedding C. psittaci heavily [13].

While an association between human psittacosis and chicken processing plants and slaughter duck farms seems possible, the interpretation of the results of the present study remains difficult. Results were not significant anymore when poultry density was removed from the model. In addition, the Dutch national infectious diseases database contains few notifications for 
psittacosis for which occupational exposure was reported or suspected.

Based on the spatial cluster of cases covering the most poultry dense area of the Netherlands it was expected that poultry farm density would end up in de multivariable model. During model selection, poultry farm density showed to lower the DIC of the model but no significant association with a higher psittacosis incidence was observed, and linked variables like the total poultry intensity did not end up in the final model. Therefore, the role of farm density remains inconclusive.

We did not find an association between psittacosis notifications and outdoor range layer presence. This finding was somewhat unexpected as outdoor range on dry soil (most poultry farms are located on sandy soil) leads to dust formation, and flocks are in close proximity to humans in the surroundings. It has to be noted that outdoor range layer presence is based on the number of places for outdoor range, not the exact number of birds that are outside (part of the time). Therefore, the results should be interpreted with caution.

A limitation of the spatial association analyses is the limited number of municipalities with chicken processing plants in the Netherlands $(N=15)$ and the resulting low power of that analysis. On the other hand, the results gain robustness due to the lack of correlation between chicken processing plants and slaughter duck farm presence mutually and with other variables. Other limitations are that people might have been infected outside their own municipality and that locations of some poultry farms were unclear. In addition, the poultry data originated from 2012 and therefore changes over time in the poultry data could not be taken into account. Also, when a farm had more than one location, we assumed equal distribution over the locations in our analyses. In practice, it is likely that the distribution is not equal and that certain types of poultry are housed at specific locations. Most importantly, we did not know whether farms were infected or not, making it difficult to make statements about a possible association.

\section{Conclusions}

This exploratory research cannot provide firm evidence for airborne transmission of psittacosis from poultry to the general population. The low number of psittacosis notifications available for analysis did not allow for detection of small differences in risk. About $80 \%$ of pneumonia patients in the Netherlands are managed in primary care, by general practitioners and current professional guidelines do not include microbiological testing in community-acquired pneumonia (CAP) [43]. Even for the 40,000 to 50,000 patients that are annually admitted to hospital in the Netherlands with pneumonia, more than $85 \%$ has an ICD-10 discharge diagnosis of 'pneumonia, organism not specified' [44]. An ongoing project aims at promoting PCR-based testing for C. psittaci in hospitalized patients with CAP to reduce this diagnostic deficit (http://www.wur.nl/nl/show/Plat4m2Btpsittacose.htm). The project will also determine the presence and prevalence of C. psittaci in animal populations, including poultry and the final product should be a 'one health' genotyping tool for C. psittaci. Together, the project activities are expected to provide better estimates of burden from human psittacosis, and the possible role of different animal reservoirs.

\section{Abbreviations \\ AIC: Akaikes Information Criterion; C. gallinacea: Chlamydia gallinacea; C. psittaci: Chlamydia psittaci; CAP: Community-acquired pneumonia; \\ CBS: Statistics Netherlands; Cl: Confidence Interval; DIC: Deviance Information Criterion; GGD: Community Health Services; INLA: Integrated Nested Laplace Approximation; MCMC: Markov chain Monte Carlo; PCR: Polymerase chain reaction; RR: Risk ratio}

\section{Acknowledgements}

We would like to thank J. van de Kassteele and B. Bom (both RIVM) for their help in the preparation of data analyses and data management.

\section{Funding}

This study was funded from the regular budget of the National Institute for Public Health and the Environment (project number V/150207) and from the Plat $4 \mathrm{~m}-2 \mathrm{Bt}-\mathrm{psittacosis}$ project, granted by ZonMw, the Netherlands Organisation for Health Research and Development (project number 522001002).

\section{Availability of data and materials}

The datasets used and/or analysed during the current study available from the corresponding author on reasonable request.

\section{Authors' contributions}

LH: Continuous feedback on research methods and statistical analyses and was a major contributor in writing and revising the manuscript. MH: Data management, statistical analyses, drafting the manuscript. EB: Wavelet analysis and contributor in writing the manuscript. FD: Osiris data preparation, multiple feedback sessions. WvdH: Conceived the study and was a major contributor in writing the manuscript. All authors discussed the results and implications and commented on the manuscript. All authors read and approved the final manuscript.

\section{Ethics approval and consent participate}

According to prevailing Dutch legislation, observational research with anonymised routine surveillance data does not fall within the remit of the Medical Research Involving Human Subjects Act and therefore does not require approval by an ethics review board [45].

Consent for publication

Not applicable.

\section{Competing interests}

The authors' declare that they have no competing interests.

\section{Publisher's Note}

Springer Nature remains neutral with regard to jurisdictional claims in published maps and institutional affiliations.

\section{Author details}

${ }^{1}$ Centre for Infectious Disease Control, National Institute for Public Health and the Environment, Bilthoven, The Netherlands. ${ }^{2}$ Currently: GD Animal Health, Deventer, the Netherlands. ${ }^{3}$ Department of Bacteriology and Epidemiology, Wageningen Bioveterinary Research, 8200 AB Lelystad, The Netherlands. 


\section{Received: 12 January 2017 Accepted: 18 July 2017}

\section{Published online: 26 July 2017}

\section{References}

1. Taylor LH, Latham SM, Woolhouse ME. Risk factors for human disease emergence. Philos Trans R Soc Lond Ser B Biol Sci. 2001;356(1411):983-9.

2. Van der Hoek W, van Gageldonk-Lafeber AB, Heddema ER, Notermans DW, Den Boer JW, Nieuwenhuizen A, et al. Omvang van het psittacoseprobleem bij de mens: het belang van betrouwbare diagnostiek. Infectieziekten Bull Extent Psittacosis Probl Hum Importance Reliable Diagn. 2014;25:45-8.

3. Kaleta EF, Taday EM. Avian host range of Chlamydiophila spp. based on isolation, antigen detection and serology. Avian Pathol. 2003;32(5):435-61.

4. West A. A brief review of Chlamydophila psittaci in birds and humans. J Exot Pet Med. 2011;20(1):18-20.

5. Harkinezhad T, Geens T, Vanrompay D. Chlamydophila psittaci infections in birds: a review with emphasis on zoonotic consequences. Vet Microbiol. 2009;135(1-2):68-77.

6. Landelijke Coördinatiestructuur Infectieziektebestrijding, RIVM. Psittacose richtlijn infectieziektenbestrijding (Psittacosis guideline infectious disease control). 2008. Accessed 3 Feb 2014.

7. Spoorenberg SM, Bos WJ, van Hannen EJ, Dijkstra F, Heddema ER, van Velzen-Blad $\mathrm{H}$, et al. Chlamydia psittaci: a relevant cause of communityacquired pneumonia in two Dutch hospitals. Neth J Med. 2016;74(2):75-81.

8. Rehn M, Ringberg H, Runehagen A, Herrmann B, Olsen B, Petersson AC, et al. Unusual increase of psittacosis in Sweden linked to wild bird exposure and focus on public health implications. Euro Surveill. 2013:18(19):20478.

9. Magnino S, Haag-Wackernagel D, Geigenfeind I. Chlamydial infections in feral pigeons in Europe: review of data and focus on public health implications. Vet Microbiol. 2009;135(1-2):54-67.

10. Hulin V, Bernard P, Vorimore D, Aaziz R, Cleva D, Robineau J, et al. Assessment of Chlamydia psittaci shedding and environmental contamination as potential sources of worker exposure throughout the mule duck breeding process. Appl Environ. 2016;82(5):1504-18.

11. Vorimore F, Thebault A, Poisson S, Cleva D, Robineau J, de Barbeyrac B, et al. Chlamydia psittaci in ducks: a hidden health risk for poultry workers. Pathog Dis. 2015;73(1):1-9.

12. Laroucau K, de Barbeyrac B, Vorimore F, Clerc M, Bertin C, Harkinezhad T, et al. Chlamydial infections in duck farms associated with human cases of psittacosis in France. Vet Microbiol. 2009;135(1-2):82-9.

13. Newman CSJ, Palmer SR, Kirby FD, Caul EO. A prolonged outbreak of ornithosis in duck processors. Epidemiol Infect. 1992;108(1):203-10.

14. Dickx V, Vanrompay D. Zoonotic transmission of Chlamydia psittaci in a chicken and turkey hatchery. J Med Microbiol. 2011;60(Pt 6):775-9.

15. Lagae S, Kalmar I, Laroucau K, Vorimore F, Vanrompay D, et al. Emerging Chlamydia psittaci infections in chickens and examination of transmission to humans. J Med Microbiol. 2014:63(Pt 3):399-407.

16. Van Loock M, Geens T, de Smit L, Nauwynck H, Van Empel P, Naylor C, et al. Key role of Chlamydophila psittaci in Belgian turkey farms in association with other respiratory symptoms. Vet Microbiol. 2005;107(1-2):91-101.

17. Hulin V, Oger S, Vorimore F, Aaziz R, de Barbeyrac B, Berruchon J, et al. Host preference and zoonotic potential of Chlamydia psittaci and C. Gallinacea in poultry. Pathog Dis. 2015;73(1):1-11.

18. Guo W, Li J, Kaltenboeck B, Gong J, Fan W, Wang C. Chlamydia gallinacea, not C. psittaci, is the endemic chlamydial species in chicken (Gallus gallus). Sci Rep. 2016;6:19638.

19. Laroucau K, Aaziz R, Meurice L, Servas V, Chossat I, Royer H, et al. Outbreak of psittacosis in a group of women exposed to Chlamydia psitacci-infected chickens. Euro Surveill. 2015;20(24):21155.

20. Deschuyffeleer TPG, Tyberghien LFV, Dickx VLC, Geens T, Saelen JM, Vanrompay D, et al. Risk assessment and management of $C$ psittaci in poultry processing plants. Ann Occup Hyg. 2012;56(3):340-9.

21. Smit L, van der Sman-de Beer F, Opstal-van Winden A, Hooiveld M, Beekhuizen J, Wouters IM, et al. Q fever and pneumonia in an area with a high livestock density: a large population-based study. PLoS One. 2012;7(6): e38843.

22. National Institute for Public Health and the Environment (RIVM). Livestock farming and the health of local residents [In Dutch]. 2016. http://www.rivm. $\mathrm{nl} /$ dsresource?objectid=2642b4ea-c205-4105-8d25-e76f230ca9eb\&type $=$ org\&disposition=inline. Accessed 24 Dec 2016.

23. Williams J, Tallis G, Dalton C, Ng S, Beaton S, Catton M, et al. Community outbreak of psittacosis in a rural Australian town. Lancet. 1998;351(9117):1697-9.
24. Klous $G$, van der Giessen J. Is er een link tussen veehouderij en het voorkomen van zoönosen bij mensen in Nederland? (Is there a link between animal husbandry and zoonotic diseases in humans in the Netherlands?) Infectieziekten. Bulletin. 2012;7:188-93.

25. National Institute for Public Health and the Environment (RIVM). Surveillance van infectieziekten: Osiris (Surveillance of infectious diseases: Osiris). 2014. http://www.rivm.nl/Onderwerpen/S/Surveillance_van_infectieziekten/ Meldingsplichtige_infectieziekten. Accessed 18 June 2014.

26. Statistics Netherlands (CBS). Agricultural census 2000-2014. http://statline. cbs.nl/StatWeb/publication/?DM=SLNL\&PA=81302NED\&D1=488-498,522532\&D2=a\&W=T. Accessed 10 June 2014.

27. Province of Utrecht. Bestand Veehouderij Bedrijven Utrecht (Animal husbandry enterprises file Utrecht). https://www.provincie-utrecht.nl/loket/ kaarten/geo/veehouderijbedrijven-0/. Accessed 20 Feb 2014.

28. Cazelles B, Chavez M, Berteaux D, Ménard F, Vik JO, Jenouvrier S, et al. Wavelet analysis of ecological time series. Oecologia. 2008;156(2):287-304.

29. Cazelles B, Chavez M, Magny GC, Guegan JF, Hales S. Time-dependent spectral analysis of epidemiological time-series with wavelets. J R Soc, Interface R Soc. 2007;4(15):625-36.

30. Torrence C, Compo GP. A practical guide to wavelet analysis. Bull Am Meteorol Soc. 1998;79(1):61-78.

31. Grinsted A, Moore JC, Jevrejeva S. Application of the cross wavelet transform and wavelet coherence to geophysical time series. Nonlinear Process Geophys. 2004;11(5/6):561-6.

32. Benincà E, Ballantine B, Ellner SP, Huisman J. Species fluctuations sustained by a cyclic succession at the edge of chaos. Proc Natl Acad Sci U S A. 2015; 112(20):6389-94.

33. Benincà E, Jöhnk KD, Heerkloss R, Huisman J. Coupled predator-prey oscillations in a chaotic food web. Ecol Lett. 2009;12(12):1367-78.

34. Kulldorff M, Nagarwalla N. Spatial disease clusters: detection and inference. Stat Med. 1995;14(8):799-810.

35. SaTScan, Software for the spatial, temporal and space-time scan statistics. 2015. http://satscan.org/. Accessed 30 Dec 2015.

36. Kulldorf M. SaTScan User Guide for version 9.4. http://www.satscan.org/cgibin/satscan/register.pl/SaTScan_Users_Guide.pdf?todo=process_userguide_ download.Jmn. Accessed 22 Sep $201 \overline{6}$.

37. R software. R: A language and environment for statistical computing. 2015. www.R-project.org. Accessed 30 Dec 2015.

38. Friesema IHM, van de Kassteele J, de Jager CM, Heuvelink AW, Van Pelt W. Geographical association between livestock density and human Shiga toxinproducing Escherichia coli 0157 infections. Epidemiol Infect. 2011;139(7): 1081-7.

39. Zeijts HV, van Eerdt MM, Willems WJ, Rood GA, den Boer AC, Nijdam DS. Towards a more sustainable livestock sector. Developments between 2000 and 2010 [in Dutch]. Den Haag/Bilthoven: The Netherlands Environmental Assessment Agency; 2010. http://www.pbl.nl/sites/default/files/cms/ publicaties/500139004.pdf. Accessed 16 May 2017

40. Winkel A. Particulate matter emission from livestock houses: measurement methods, emission levels and abatement systems. Wageningen University. 2016. http://edepot.wur.nl/390454. Accessed 10 Nov 2016.

41. Association of Dutch Poultry Processing Industries (NEPLUVI). Hygiënecode pluimveeslachterijen en -uitsnijderijen. http://www.nepluvi.nl/page/323/ hygienecode-2013-pluimveeslachterijen-en-uitsnijderijen.html. Accessed 24 July 2017.

42. Van Krimpen M, Poelarends J, Bremmer B, Spoelstra S. Eersteklas eend, adviesdocument. Wageningen UR Livestock Research Lelystad. 2011. http:// edepot.wur.nl/160272. Accessed 2 May 2014.

43. Snijders BEP, van der Hoek W, Stirbu I, van der Sande MAB, van GageldonkLafeber AB. General practitioners' contribution to the management of community-acquired pneumonia in the Netherlands: a retrospective analysis of primary care, hospital, and national mortality databases with individual data linkage. Prim Care Respir J. 2013;22(4):400-5.

44. Benincà E, van Boven M, Hagenaars T, van der Hoek W. Space-time analysis of pneumonia hospitalisations in the Netherlands. PloS one. 2017;12(7): e0180797.

45. Central Committee on Research Involving Human Subjects. Medical/ scientific research and the WMO. http://www.ccmo.nl/en/medical-scientificresearch-and-the-wmo. Accessed 22 June 2017. 